\title{
Novel Production of Interleukin-1 Receptor Antagonist Peptides in Normal Human Cornea
}

\author{
Michael C. Kennedy, ${ }^{\star \ddagger}$ James T. Rosenbaum, ${ }^{\text {t\$ }} \|$ Jeffrey Brown, ${ }^{1}$ Stephen R. Planck, ${ }^{\text {t\$ } \|}$ Xiaona Huang," \\ Cheryl A. Armstrong, ${ }^{\star 1}$ and John C. Ansel**\|1 \\ Departments of *Dermatology, ${ }^{\ddagger}$ Cell Biology and Anatomy, ${ }^{8}$ Medicine, and $"$ Ophthalmology, Oregon Health Sciences University and \\ Casey Eye Institute; and 'Dermatology Service, Veterans Affairs Medical Center, Portland, Oregon 97207
}

\begin{abstract}
Interleukin-1 receptor antagonist (IL-1ra) is an important modulator of IL-1 activity in a variety of tissues. IL-1ra is differentially produced by different cell types as a 22-26. kD secreted peptide (sIL-1ra) and/or a smaller 16- or 18kD intracellular peptide (icIL-1ra). This study was undertaken to evaluate the production of IL-1ra in the human cornea. IL-1ra mRNA can be detected in early passage human corneal epithelial cells and corneal stromal fibroblasts and is significantly enhanced by IL-1. Corneal endothelial cells do not express IL-1ra mRNA. Immunohistochemical studies of cultured corneal cells and whole human cornea demonstrate IL-1ra protein production by both the epithelial and stromal cells but not the endothelial cells. Reverse transcriptase polymerase chain reaction, ELISA, and immunoprecipitation studies indicate that corneal epithelial cells are capable of producing both icIL-1ra and sIL-1ra forms of IL-1ra whereas the corneal stromal cells produce only icIL-1ra. In addition to the larger 18-kD icIL-1ra, both corneal epithelial and stromal cells are also capable of producing a smaller recently described 16-kD icIL-1ra. Thus, the differential production of IL-1ra in the human cornea is unique; whereas both epithelial and stromal cells produce icIL-1ra (type 1 and type 2), the epithelial cells appear to also produce sIL-1ra. It is proposed that these IL-1ra proteins may play an important role in regulating $\mathrm{IL-1-induced}$ corneal inflammation. (J. Clin. Invest. 1995. 95:82-88.) Key words: corneal epithelial cells - corneal stromal fibroblasts - corneal inflammation • interleukin-1 • secreted interleukin1 receptor antagonist
\end{abstract}

\section{Introduction}

Cytokines have been implicated as important mediators of inflammation and tissue damage in the cornea $(1-6)$. It has been demonstrated by our group and others that corneal cells are capable of producing a number of inflammatory cytokines including the potent immunomodulating cytokine interleukin 1 (IL-1) (7-14). Increased tissue IL-1 production has been detected in many inflammatory disease states $(15,16)$. In the eye, intravitreal injection of IL-1 produces an acute anterior uveitis

Address correspondence to John C. Ansel, M.D., Emory University School of Medicine, 1639 Pierce Drive, Department of Dermatology, 5311 WMB, Atlanta, GA 30322. Phone: 404-727-5107; FAX: 404-7275217.

Received for publication 8 July 1994 and in revised form 8 September 1994.

The Journal of Clinical Investigation, Inc.

Volume 95, January 1995, 82-88 in animal models (1-3) and release of IL-1 from implanted intracorneal pellets results in corneal neovascularization (17). Corneal inflammation and neovascularization have been reported in transgenic mice in which high intraocular constitutive production of $\mathrm{IL}-1 \beta$ was generated by using a crystalline gene promotor construct $(18,19)$. Furthermore, the addition of IL1 to cultured corneal cells augments the production of interleukin 8 (IL-8) and the expression of intracellular adhesion molecule-1 (ICAM-1) which could initiate the inflammatory cascade in the cornea $(20,21)$.

Factors which inhibit the effect of IL-1 on various target cells may play an important role in modulating corneal inflammation. The $\mathrm{IL}-1$ receptor antagonist (IL-1ra) ${ }^{1}$ is a recently characterized molecule that acts as a pure antagonist of biologically active IL-1 $(22,23)$. IL-1 ra blocks cellular responses to IL-1 by binding almost irreversibly to the IL-1 receptor without triggering signal transduction $(24,25)$. Alternatively spliced products of the IL-1ra gene result in two forms of IL-1ra designated secreted IL-1ra (sIL-1ra) and intracellular IL-1ra (icIL1ra) which are produced differentially in various cell types and may have distinct biologic roles in modulating IL-1-induced responses (26). For example monocytes, macrophages, neutrophils, and hepatocytes have been reported to secrete sIL-1ra whereas icIL-1ra is produced by fibroblasts, macrophages, and epithelial cells (26). In addition, a second smaller form of icIL1 ra $(16 \mathrm{kD})$ has been recently described which appears to have a similar function as the larger $18-\mathrm{kD}$ form of icIL-1ra (27, 28). As an antagonist of IL-1, IL-1ra has been demonstrated to inhibit IL-1 inducible events both in vitro and in vivo (2934 ). We have demonstrated that the administration of IL-1 ra effectively blocks the onset of IL-1-induced uveitis in a rabbit model (35). However, little is known regarding the production and regulation of IL-1ra in the eye. In this investigation we examine the production of sIL-1ra and icIL-1 ra in human corneal cells and whole cornea. The production of IL-1ra by the cornea may have important consequences for modulating IL1 -mediated inflammation and tissue repair in the anterior chamber of the eye.

\section{Methods}

Isolation and culture of human corneal cells. Primary human corneal epithelial cell cultures were established by aseptically scraping the epithelial layer of transplant quality human corneas obtained from the Oregon Lion's Eye Bank (Portland, OR) using a No. 15 scalpel after a $1 \mathrm{~h}$ Dispase (Boehringer Mannheim, Indianapolis, IN) treatment at $37^{\circ} \mathrm{C}$. Cells were obtained from three sets of freshly removed corneas (six corneas). The donors were 40,60, and 65 years old and had no

1. Abbreviations used in this paper: icIL-1ra, intracellular IL-1 receptor antagonist; IL-1ra, IL-1 receptor antagonist; sIL-1 ra, secreted IL-1 receptor antagonist. 
underlying ocular disease. All studies were carried out at least three times and results from representative experiments are presented. Cells were then cultured in medium 154 supplemented with bovine pituitary extract, bovine insulin, hydrocortisone, human transferrin, and human epidermal growth factor (Cascade Biologicals, Portland, OR) with media changes every $48 \mathrm{~h}$ until subconfluent.

Primary human corneal stromal cell cultures were established from tissue obtained as described above from the Oregon Lion's Eye Bank by removal of the central cornea using an 8 -mm biopsy punch after scraping away the epithelial layer. After removal of Descemet's membrane, the corneal stroma was minced with scissors and cultured in MCDB 402 media with $10 \%$ fetal calf serum. Media was changed every $48 \mathrm{~h}$ until cells were subconfluent.

Primary human corneal endothelial cells were isolated from tissue obtained as described above by scraping this layer of cells from Descemet's membrane. Endothelial cells were pooled from the three donor corneas and total RNA was extracted for use in RT-PCR studies.

Immunohistochemistry for detection of IL-1 ra. For immunohistochemistry studies, epithelial cells and stromal fibroblasts were harvested by trypsinization after $2-3 \mathrm{wk}$, washed, replated onto $22-\mathrm{mm}$ cover slips in six well plates, and cultured in supplemented medium 154 until $90 \%$ confluent. Cells were stimulated with human IL- $1 \alpha(20 \mathrm{U} / \mathrm{ml}, \sim 1$ $\times 10^{-6} \mathrm{mg}$ ) (Genzyme Corp., Cambridge, MA) for $6 \mathrm{~h}$, washed three times in cold Hank's balanced salt solution (HBSS), fixed for $10 \mathrm{~min}$ in $1 \%$ para-formaldehyde PBS at $4^{\circ} \mathrm{C}$, then washed three times in cold HBSS. Fixed monolayers of human corneal epithelial cells were blocked for 30 min with HBSS $5 \%$ normal horse serum, then stained with either $5 \mu \mathrm{g} / \mathrm{ml}$ murine monoclonal antibody to IL-1 ra (a kind gift of Dr. W. Arend, University of Colorado Health Sciences Center, Denver, CO) or $5 \mu \mathrm{g} / \mathrm{ml}$ of purified preimmune mouse IgG for $1 \mathrm{~h}$ at $25^{\circ} \mathrm{C}$. Slides were washed three times and stained for $1 \mathrm{~h}$ with a 1:200 dilution of alkaline phosphatase conjugated horse anti-mouse IgG (Vector Laboratories, Inc. Burlingame, CA). Slides were developed using TR Fast Red substrate (Pierce, Rockford, IL) which leaves a red precipitate where alkaline phosphatase activity is localized. Slides serving as negative controls were counterstained with methylene blue to allow cellular morphology to be visualized. Monolayers were photographed using bright field/phase contrast double exposure with a Nikon inverted microscope.

For immunohistochemistry of whole human cornea, transplant quality corneas were harvested within $1 \mathrm{~h}$ postmortem, (Lion's Eye Bank) and held in Optisol at $4^{\circ} \mathrm{C}$ for $6-8 \mathrm{~h}$ before embedding. Corneas were washed three times with HBSS $\left(\mathrm{Ca}^{2+} / \mathrm{Mg}^{2+}\right.$ free $)$ then embedded in O.C.T. (Miles Inc., Elkhart, IN), frozen in liquid $\mathrm{N}_{2}$, and stored at $-70^{\circ} \mathrm{C}$ until sectioned. Tissue blocks were warmed to $-12^{\circ} \mathrm{C}$ and $8-\mu \mathrm{M}$ sections were cut on a Minotome (International Equipment Company, Needham, MA). Sections were mounted on glass slides and fixed for $5 \mathrm{~min}$ in acetone at $4^{\circ} \mathrm{C}$, then washed three times in HBSS. Sections were blocked and stained as above. After developing with Fast Red TR, sections were fixed for $5 \mathrm{~min}$ in $2 \%$ glutaraldehyde in PBS at $4^{\circ} \mathrm{C}$, counterstained with hematoxylin and eosin, and photographed under bright field illumination with a Nikon inverted microscope.

Determination of secreted and cell-associated IL-1ra by ELISA. Cultured human corneal epithelial cells and human corneal stromal fibroblasts were grown to near confluence then either treated with fresh basal media (unstimulated) or media supplemented with recombinant human IL-1 $\alpha(20 \mathrm{U} / \mathrm{ml})$ (Genzyme) for $48 \mathrm{~h}$. Cell supernatants were collected and stored at $-20^{\circ} \mathrm{C}$. Cell lysates were prepared by collecting cultured cells using $10 \mathrm{mM}$ EDTA in HBSS $\left(\mathrm{Ca}^{2+} / \mathrm{Mg}^{2+}\right.$ free $)$ at $4^{\circ} \mathrm{C}$ and centrifugation $(1,500 \mathrm{~g})$ for $10 \mathrm{~min}$. Cell pellets were lysed in PBS with $1 \%$ NP-40, $10 \mathrm{mM}$ EDTA, $2 \mathrm{mM}$ PMSF, and $10 \mu \mathrm{g} / \mathrm{ml}$ each of Leupeptin, Pepstatin A, Antipain, Chymostatin (Sigma Chemical Co., St. Louis, MO) on ice for $20 \mathrm{~min}$, then clarified by centrifugation $\left(10,000 \mathrm{~g}\right.$ for $20 \mathrm{~min}$ at $\left.4^{\circ} \mathrm{C}\right)$. Both cell lysates and tissue culture supernatants were tested for IL-1ra using a commercially available ELISA kit (R\&D Systems, Minneapolis, MN).

Northern blot analysis. For Northern blot analysis, corneal epithelial cells and stromal fibroblasts were grown to near confluence then either treated with fresh basal media (unstimulated) or media supplemented with recombinant human IL-1 $\alpha(20 \mathrm{U} / \mathrm{ml})$ (Genzyme) for $6 \mathrm{~h}$ prior to cell harvest. Poly ( A $)^{+}$mRNA was isolated by the oligo(dT)-cellulose affinity chromatography method (36) and mRNA levels were determined by Northern blot analysis as previously described (37). The human IL-1 ra cDNA probe used in these studies was generously provided by D. Carter (Upjohn Inc., Kalamazoo, MI). This probe will detect mRNA for both icIL-1 ra and sIL-1 ra. Equivalent loading of RNA in each lane was confirmed by hybridizing the blots with the cDNA probe for the gene cyclophilin (1B15), which was generously provided by J. Douglass (Oregon Health Sciences University, Portland, OR).

Reverse transcriptase polymerase chain reaction using specific icILIra and sIL-Ira primers. PCR analysis of steady state mRNA from human corneal epithelial, stromal, and endothelial cells was conducted as follows. Poly (A) ${ }^{+}$selected mRNA (15 ng) or total RNA (200 ng) was added to a reaction mixture of $20 \mathrm{U}$ of M-MLV reverse transcriptase (GIBCO BRL Life Technologies, Gaithersburg, MD) with $500 \mu \mathrm{m}$ dNTPs, $1 \mathrm{U}$ Rnasin and $200 \mathrm{ng}$ of oligo $\mathrm{dT}$ for $2 \mathrm{~h}$ at $37^{\circ} \mathrm{C}$. PCR primers were made by Operon Technols., Inc. (Alameda, CA) as follows, for icIL-1ra 5'-GAA GTT GAG TTA GAG TCT GAA A, for sIL-1ra 5'GAA TGG AAA TCT GCA GAG GCC TCC GC and 5'-TGA CAT TTG GTC CTT GCA AGT A, as second primer for both iclL-1 ra and sIL-1 ra, for common IL-1 ra sequence 5'-GCA AGA TGC AAG CCT TCA GAA TCT GGG and 5'-GCT GGT CAG CTT CCA TCG CTG TGC A. Reverse transcriptase products were subjected to 25 rounds of amplification using a Perkin Elmer model 9600 thermo-cycling apparatus set as follows: $95^{\circ} \mathrm{C} 5 \mathrm{~min}+94^{\circ} \mathrm{C} 15 \mathrm{~s}$ for denaturation, $55^{\circ} \mathrm{C} 1$ min for annealing, $72^{\circ} \mathrm{C} 2 \mathrm{~min}$ for extension. The total volume of the reaction mixture was $25 \mu \mathrm{l}$ with $3 \mathrm{mM} \mathrm{Mg}{ }^{2+}, 4 \mathrm{mM}$ dNTPs, $0.6 \mathrm{U}$ of TFL polymerase (Epicentre Technologies Corp., Madison, WA) and 20 pmole of specific primer and/or 2.5 pmole of $1 \mathrm{~B} 15$ primer. PCR products were separated by electrophoresis through $3 \%$ agarose gels.

IL-Ira ${ }^{35} \mathrm{~S}$ labeling and immunoprecipitation. Human corneal epithelial and stromal cells were $\left[{ }^{35} \mathrm{~S}\right]$ cysteine/methionine labeled as previously described (38). Subconfluent cultures of epithelial cells and stromal fibroblasts were stimulated for $3 \mathrm{~h}$ with $20 \mathrm{U} / \mathrm{ml}$ of $\mathrm{IL}-1 \alpha$ (Genzyme Corp.), washed two times with cysteine/methionine free media 154XP (Cascade Biologics), and labeled for $18 \mathrm{~h}$ at $37^{\circ} \mathrm{C}$ with EXPRE ${ }^{35} \mathrm{~S}^{35} \mathrm{~S}$ labeling mix (NEN Dupont, Wilmington, DE) at 100 $\mu \mathrm{Ci} / \mathrm{ml}$ in $154 \mathrm{XP}$ media. After labeling, cell supernatants were collected and cells were washed three times in HBSS, then lysed in 1\% NP-40 extract buffer ( $100 \mathrm{mM} \mathrm{NaCl}, 10 \mathrm{mM}$ Tris, pH 7.4, 5 mM EDTA, 2 $\mathrm{mM}$ PMSF). Cell lysates were clarified by centrifugation at 10,000 $\mathrm{g}$ and culture supernatants and cell lysates were concentrated with Centriprep 10 columns (Amicon Corp., Beverly, MA) and combined. Before immunoprecipitation, samples were precleared once with protein ASepharose and preimmune rabbit $\operatorname{lgG}(25 \mu \mathrm{g} / \mathrm{sample})$ followed by protein A-Sepharose two times. For immunoprecipitation, $25 \mu \mathrm{g} / \mathrm{sam}$ ple of rabbit polyclonal anti-IL-1ra antibody (Genzyme Corp.) was bound to protein A-Sepharose with an antibody orientation kit (Pierce). We have previously used this antibody in immunoprecipitation/Western blotting assays and have observed that it precipitates a $17-\mathrm{kD}$ band from solutions of recombinant human IL-1 ra (data not shown). After binding antibody, protein-A sepharose was recovered by centrifugation ( 1000 $g$ ) for $10 \mathrm{~min}$ and washed three times in TBS. Samples were then eluted into $25 \mu \mathrm{l}$ of SDS sample buffer containing 2-Me, heated for $5 \mathrm{~min}$ at $95^{\circ} \mathrm{C}$, microfuged for $1 \mathrm{~min}$, and subjected to electrophoresis through $15 \%$ acrylamide SDS gels and autoradiography at $-80^{\circ} \mathrm{C}$ using Kodak X-OMAT AR film. PMA-differentiated U937 monocytic cells (IL-1 ra producer) (39) served as a positive control and the G361 human melanoma cell line (non-IL-1 ra producer) was used as a negative control for these studies.

\section{Results}

Expression of IL-1ra mRNA in human corneal epithelial and stromal cells. IL-1 ra mRNA expression was measured in cultured human corneal epithelial cells and corneal stromal fibroblasts by Northern blot analysis (Fig. 1). As indicated in this figure, human corneal epithelial cells constitutively express IL- 


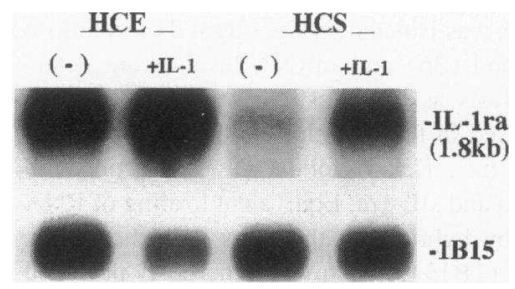

Figure 1. IL-1ra mRNA expression by human corneal epithelial cells and human corneal stromal fibroblasts. The expression of IL-1ra mRNA was determined in human corneal epithelial cells $(H C E)$ and human corneal stromal fi-

broblasts $(H C S)$ by Northern blot analysis using a ${ }^{32} \mathrm{P}$-labeled cDNA probe specific for human IL-1ra. Each lane contains $5 \mu \mathrm{g}$ poly (A) ${ }^{+}$ RNA from either unstimulated cells (-) or cells stimulated with IL- $1 \alpha$ $(20 \mathrm{U} / \mathrm{ml})$ for $6 \mathrm{~h}$. Equivalent loading of RNA was verified by hybridizing each blot with a ${ }^{32} \mathrm{P}$-labeled cDNA probe for cyclophilin (1B15).

1ra mRNA ( $1.8 \mathrm{~kb})$, while only low levels of IL-1ra mRNA are detected in unstimulated human corneal stromal fibroblasts. After the addition of recombinant human IL- $1 \alpha(20 \mathrm{U} / \mathrm{ml})$ for 6 $h$ to the cultured epithelial and stromal cells, there are significant levels of IL-1 ra mRNA detected in both corneal epithelial cells and corneal stromal cells. Equivalent loading is confirmed by hybridization to the ${ }^{32} \mathrm{P}$-labeled cDNA probe for the $1 \mathrm{~B} 15$ gene. It should be noted that high levels of IL-1 ra mRNA are detected in the IL-1-treated human corneal epithelial cells in spite of relatively less mRNA loaded in this lane. Thus, both corneal stromal cells and epithelial cells are capable of expressing IL1ra mRNA.

Production of IL-1ra protein by human corneal epithelial and stromal cells. The production of IL-1 ra peptide by corneal epithelial cells and stromal fibroblasts was determined by immunohistochemistry (Fig. 2). In this representative figure, monolayers of both corneal epithelial and stromal cells stain positively for IL-1ra using a primary anti-human IL-1 ra antibody (Fig. 2, $A$ and $C$ ). The specificity of this result is confirmed by the absence of staining when pre-immune $\operatorname{IgG}$ is used as the primary antibody (Fig. 2, $B$ and $D$ ). These control slides were stained with methylene blue for visualization of cellular morphology. Thus, both human corneal epithelial and stromal cells produce IL-1ra protein in vitro.

Immunolocalization of IL-Ira in whole human cornea. The production of corneal IL-1ra protein was then immunolocalized in freshly isolated whole human cornea (Fig. 3). Immunohistochemical staining of this tissue demonstrates prominent staining for IL-1ra in the epithelial layers ( $E P$ ) of the cornea (Fig. $3 A$ ) especially in the more differentiated suprabasal cells. Likewise, there is definite staining of individual stromal cells $(S)$ in the corneal stroma indicating that these cells also produce IL-1 ra (Fig. $3 \mathrm{~A}$, arrow). In contrast, no IL-1ra is detected in the endothelial layer $(E N)$ of the cornea (Fig. $3 B$ ). Staining specificity is confirmed by the use of preimmune mouse IgG as a control antibody (Fig. $3 \mathrm{C}$ ). These studies thus localize IL-1ra production to both corneal epithelium and stroma but not to the corneal endothelial layer.

Differential production of icIL-1 ra and sIL-1 ra mRNA by human corneal epithelial and stromal cells. Two forms of IL1ra have been identified: icIL-1ra and sIL-1ra. Using specific IL-1ra oligonucleotide primers, the expression of both icIL-1 ra and sIL-1ra mRNA was measured in corneal cells. These two forms of IL-1 ra are differentially produced by various cell types and may have distinct intracellular and extracellular biologic roles in mediating IL-1 inflammatory responses. After RT-PCR amplification, IL-1ra mRNA is detected in both corneal epithe- lial cells and stromal fibroblasts (Fig. 4). Both corneal cell types express the 266-bp PCR product for icIL-1ra (Fig. 4, lanes 3-6). Unexpectedly, corneal epithelial cells also express sIL-1ra mRNA (201 bp product) both constitutively and after the addition of IL- $1 \alpha$ to the cultured cells (Fig. 4, lanes 3 and 4). To our knowledge, this is the first example of a true epithelial cell expressing the secreted form of IL-1ra. In contrast, the stromal fibroblasts do not express sIL-1 ra mRNA (Fig. 4, lanes 5 and 6 ). Neither iclL-1 ra mRNA nor sIL-1 ra mRNA is detected by RT-PCR in the corneal endothelial cells (data not shown). This is in agreement with the immunohistochemistry studies which failed to demonstrate staining of the endothelial layer with an IL-1ra antibody. Synovial fibroblast mRNA derived from a patient with rheumatoid arthritis serves as a positive control for icIL-1 ra and sIL-1ra (Fig. 4, lane 1) and human dermal microvascular endothelial cell mRNA serves as a negative control (no IL-1ra expression) for these studies (Fig. 4, lane 2). Since these RT-PCR studies are not quantitative, no conclusion can be drawn regarding the lack of induction of IL1ra by IL-1 in this figure (Fig. 4, lanes 3 and 5) compared with the Northern blot in Fig. 1. Thus, these studies demonstrate the differential expression of icIL-1 ra and sIL-1 ra mRNA in corneal epithelial and stromal cells as well as the unique production of sIL-1 ra mRNA by corneal epithelial cells.

Differential production of IL-1 ra protein by human corneal epithelial and stromal cells. IL-1ra in corneal cell lysates and supernatants was also examined by ELISA in triplicate using cells from three different corneas. Significant amounts of IL-1 ra are detected in supernatants and cell lysates from unstimulated epithelial cells which increased following the addition of IL$1 \alpha(20 \mathrm{U} / \mathrm{ml})$ to the cultured cells (Fig. 5). Likewise, cell lysates from corneal stromal fibroblasts (unstimulated and stimulated with IL- $1 \alpha$ ) contain quantities of IL-1ra similar to those detected in the epithelial cell lysates (Fig. 5). In contrast to corneal epithelial cells, no IL-1ra is detected in stromal cell supernatants. Thus these studies are consistent with our previous PCR studies in Fig. 4 which indicate that human corneal epithelial cells are capable of producing both icIL-1ra and sIL-1ra whereas stromal cells apparently produce only icIL-1 ra.

The production of IL-1ra peptides in corneal epithelial and stromal cells was further examined by cellular metabolic labeling studies with ${ }^{35} \mathrm{~S}$ followed by immunoprecipitation with an IL-1 ra specific antisera. These studies indicate that both corneal epithelial cells and stromal cells produce both a 16- and $18-\mathrm{kD}$ form of IL-1ra (Fig. 6, lanes 1 and 2) which is consistent with previously reported sizes of icIL-1ra(1) and icIL-1ra(2) (27, 28 ). Additionally, in the epithelial cells, a $22-\mathrm{kD}$ band is detected which is identical to the previously reported (26) glycosylated secreted form of IL-1ra (Fig. 6, lane 1). As a positive control, immunoprecipitation studies were carried out with the U937 monocytic cell line which has been reported to produce both the intracellular and secreted forms of IL-1ra (39). As indicated, bands of 16,18 , and $22 \mathrm{kD}$ are clearly produced by this cell line (Fig. 6, lane 3). As a negative control, the G361 human melanoma cell line which does not produce IL-1 ra was utilized (Fig. 6, lane 4). These studies further support the unique observation that corneal epithelial cells are capable of producing both secreted and intracellular IL-1 ra (type 1 and type 2 ) whereas stromal cells apparently produce only icIL-1 ra (type 1 and type 2).

\section{Discussion}

IL-1 is a potent immunomodulating cytokine with pleiotrophic effects on a variety of tissues $(15,16)$. The role of IL-1 $\alpha$ and 

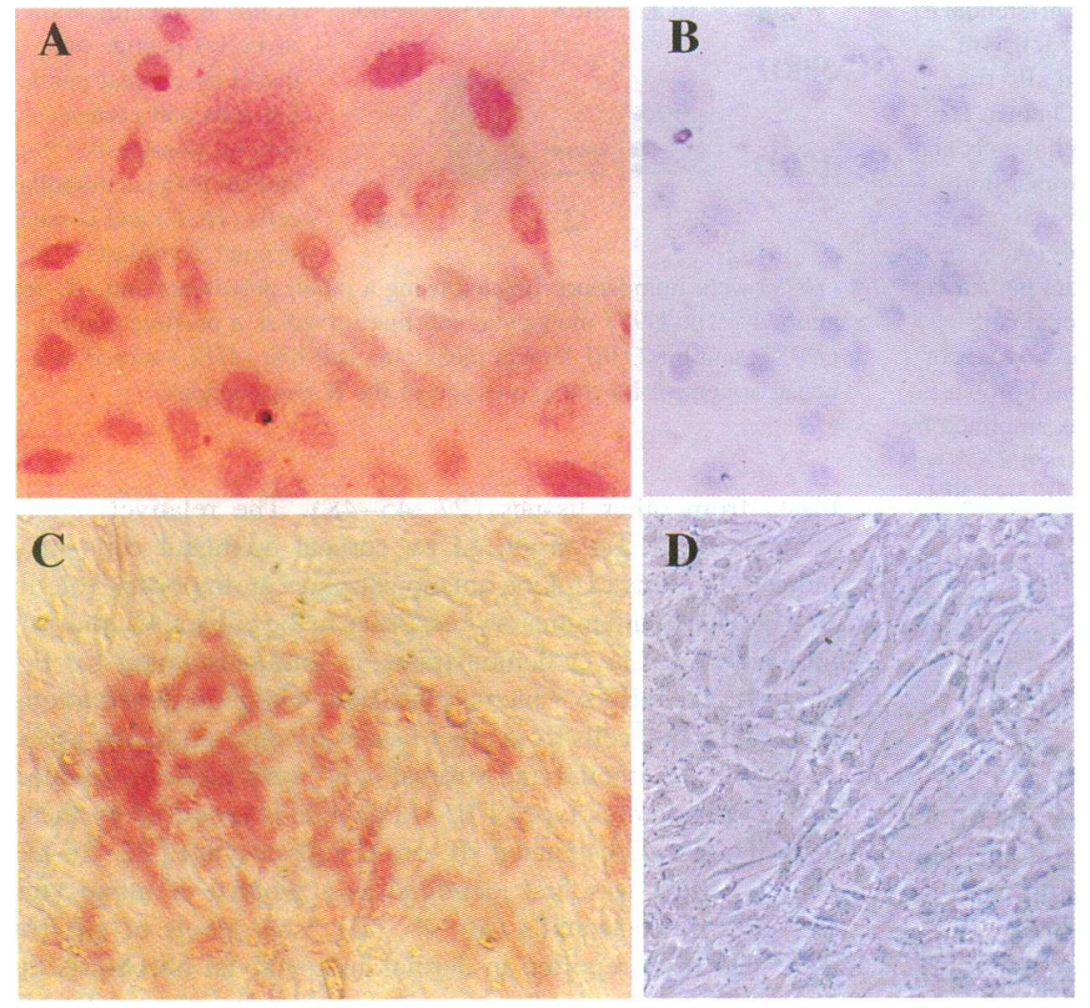

Figure 2. Immunodetection of IL-1 ra in cultured human corneal epithelial cells and comeal stromal fibroblasts. Monolayers of human corneal epithelial cells $(A)$ and human corneal stromal fibroblasts $(C)$ were stained with a monoclonal murine anti-IL-1 ra antibody followed by secondary alkaline phosphatase conjugated goat anti-mouse IgG. Negative controls included human corneal epithelial cells $(B)$ and corneal stromal fibroblasts $(D)$ stained with preimmune mouse IgG as the primary antibody followed by secondary alkaline phosphatase conjugated goat anti-mouse IgG then counterstained with methylene blue to allow the cellular morphology to be visualized.
IL- $1 \beta$ as well as other inflammatory cytokines in mediating inflammation and tissue damage in the eye has been evaluated with in vivo models of ocular disease $(1-3,17-19)$. Studies of isolated corneal cells also support the role of IL-1 as a potential mediator of inflammation $(20,21,40-42)$. The relevance of IL-1 in corneal inflammation is further supported by observa- tions that corneal cells themselves can produce this cytokine in response to various stimuli $(7-9,13,14,43,44)$.

In this report, we have demonstrated for the first time that IL-1ra mRNA and protein are produced in human corneal cells and whole human cornea. As determined by Northern blot analysis, human corneal epithelial cells constitutively produce IL-
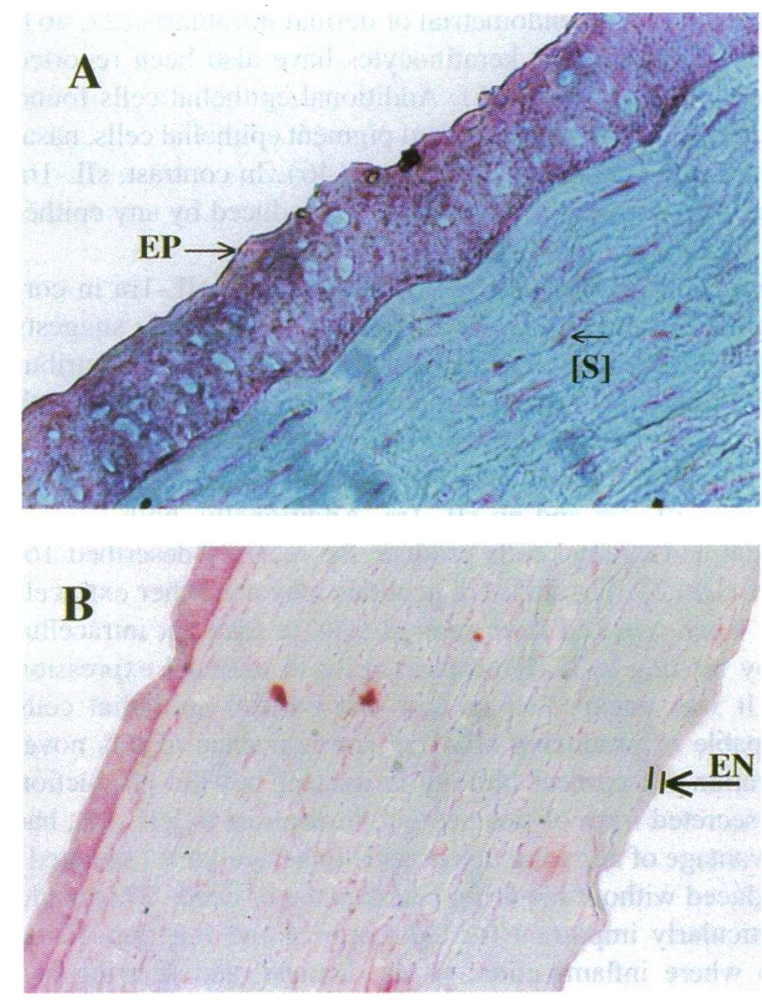

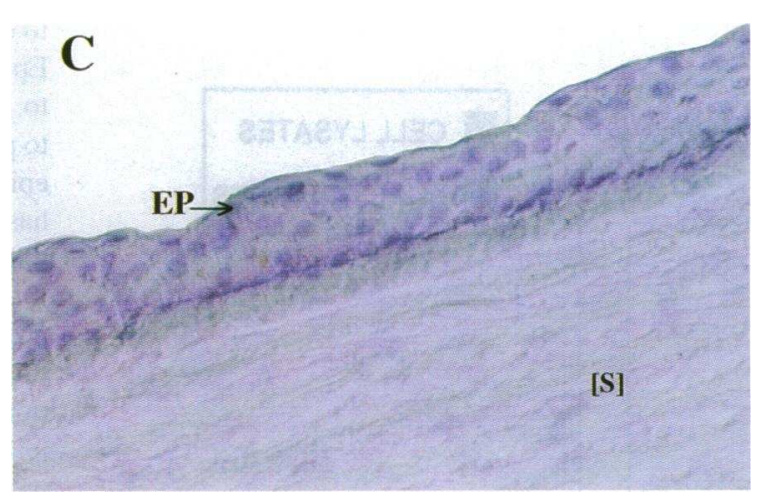

Figure 3. Immunolocalization of IL-1ra in whole human cornea. Immunohistochemistry was performed on human cornea sections using a monoclonal murine anti-IL-1ra antibody followed by alkaline phosphatase conjugated goat antimouse IgG as the secondary antibody. The epithelial $(E P)$ and stromal $(S)$ layers are shown in $A(\times 400)$ with individual stromal cells indicated by an arrow. The endothelial (EN) layer is indicated by the arrow in $B(\times 200)$. Staining specificity was evaluated by the use of preimmune mouse $\operatorname{IgG}$ as a control antibody in $C$ $(\times 400)$. 


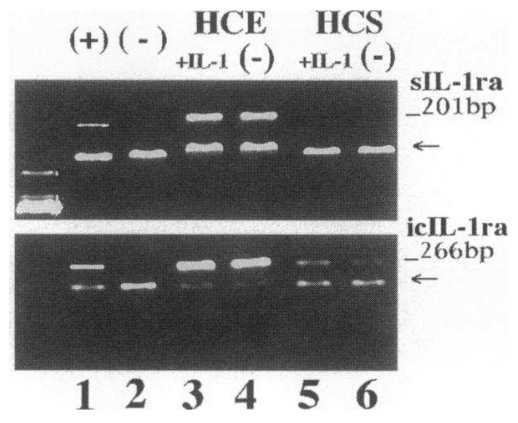

PCR using primers specific for icIL-1 ra and sIL-1ra. IL-1 ra mRNA was measured in both uninduced cells and cells treated with IL-1 $\alpha(20 \mathrm{U} /$ $\mathrm{ml}$ ) for $6 \mathrm{~h}$. Rheumatoid arthritis synovial fibroblast mRNA (+, lane 1) served as a positive control and microvascular endothelial cell mRNA $(-$, lane 2$)$ served as a negative control for both iclL-1ra (266 bp) and sIL-1ra (201 bp). 1B15 gene specific primers (arrows) were used as loading and amplification controls.

1 ra with increased production after the addition of IL- $1 \alpha$ whereas IL-1ra mRNA is expressed in corneal stromal fibroblasts at significant levels only after IL- $1 \alpha$ induction. IL-1 ra protein production is likewise demonstrated in both cultured epithelial and stromal cells by immunohistochemistry. Similarly, immunohistochemical analysis of whole human cornea reveals prominent staining for IL-1ra in the epithelial layer and staining of individual stromal cells within the stromal layer of the cornea. The epithelial layer stained more intensely in the more differentiated suprabasal layer which is consistent with previous reports in which increased IL-1 ra was detected in more differentiated epidermal cells (27). The ability of corneal epithelial and stromal cells to produce IL-1ra is consistent with the reported production of IL-1ra by epithelial cells and fibro-

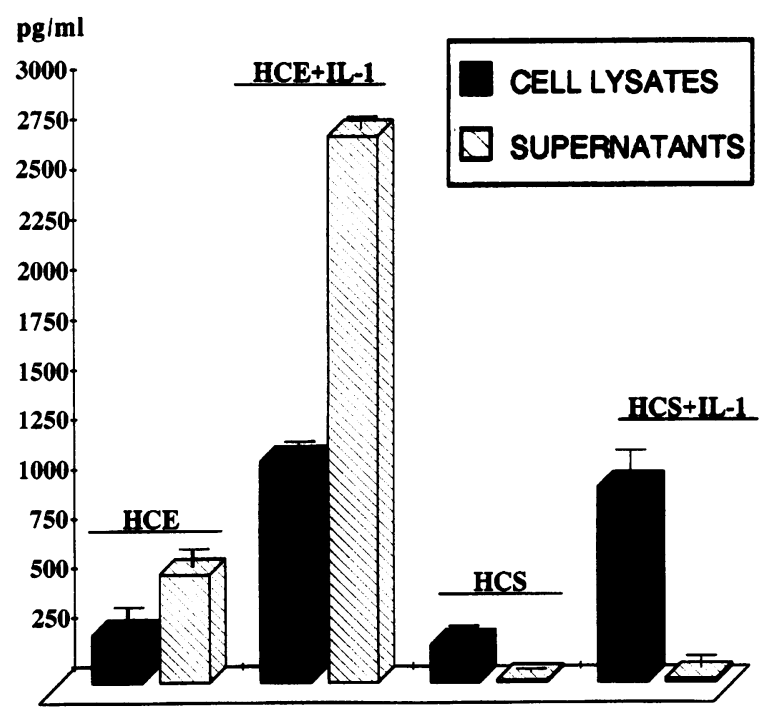

Figure 5. Differential production of IL-1ra peptide by human corneal epithelial and stromal cells. IL-1 ra production in human corneal epithelial cells $(H C E)$ and corneal stromal fibroblasts $(H C S)$ was evaluated in unstimulated cultured cells or cells pretreated with IL-1 $\alpha(20 \mathrm{U} / \mathrm{ml})$ for $48 \mathrm{~h}$. Both cell associated IL-1 ra (lysates) and secreted IL-1 ra (supernatants) were measured by ELISA with SD indicated by error bars.

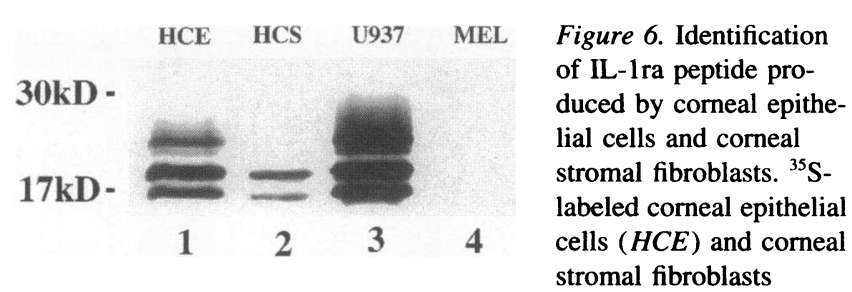

(HCS) were immunoprecipitated using a rabbit polyclonal anti-IL-1 ra antibody. The U937 monocytic cell line served as a positive control (U937) and the G361 human melanoma cell line (MEL) served as a negative control for the expression of the IL-1ra peptides.

blasts from other tissues $(27,45-48)$. The relatively large amounts of IL-1ra produced by corneal epithelial cells may indicate that this cytokine antagonist plays an important role in IL-1 -induced inflammatory responses in the cornea. In contrast, the endothelial layer demonstrates no immunostaining for IL1 ra or IL-1 ra mRNA which is consistent with prior observations that endothelial cells from other tissues produce no IL-1ra (46).

Corneal epithelial and stromal cells were further evaluated to determine which type of IL-1 ra peptide is produced by these cells. The form designated sIL-1 ra is a glycosylated $22-26-\mathrm{kD}$ peptide which was first identified as a product of monocytes and later of neutrophils $(46,49,50)$. Low levels of sIL-1 ra have also been reported in dermal and synovial fibroblasts by some investigators while other studies demonstrate no sIL-1 ra production by these cell types $(27,46-48)$. A second form of IL-1 ra designated intracellular IL-1 ra (icIL-1 ra) is a nonglycosylated $18-\mathrm{kD}$ molecule that resides in a cell-associated compartment (46). More recently, a smaller 16-kD icIL-1 ra(2) peptide has also been described $(27,28)$. This intracellular peptide appears to function in a similar fashion as the larger 18 $\mathrm{kD}$ icIL-1ra(1) $(27,28)$. Dermal and synovial fibroblasts have been reported to produce significantly more iclL-1 ra than sIL1 ra suggesting that icIL-1ra is the major form of this protein synthesized by these cells $(47,48)$. Other studies were unable to detect icIL-1 ra in endometrial or dermal fibroblasts $(27,46)$. Epithelial cells such as keratinocytes have also been reported to produce icIL-1ra $(27,46)$. Additional epithelial cells found to produce icIL-1 ra include retinal pigment epithelial cells, nasal epithelium, and bronchial epithelium (46). In contrast, sIL-1 ra has not been previously reported to be produced by any epithelial cell types.

The differential production of sIL-1ra and icIL-1 ra in corneal epithelial and stromal cells reported in our study suggests that corneal cells exhibit a unique pattern of IL-1 ra cell distribution. We found that human corneal epithelial cells produce both icIL-1ra and sIL-1ra based on ELISA, RT-PCR, and immunoprecipitation. In contrast, human corneal stromal fibroblasts produce only icIL-1ra and no sIL-1 ra. Additionally, both corneal epithelial and stromal cells produce the recently described 16$\mathrm{kD}$ icIL-1ra(2). The icIL-1 ra peptides may act either extracellularly when released from injured cells or may act intracellularly by binding to IL-1 receptors prior to external expression (27). It was unexpected to find that corneal epithelial cells are capable of producing sIL-1ra. The relevance of this novel observation for corneal biology is unclear but the production of the secreted form of this peptide, in contrast to icIL-1ra, has the advantage of allowing this peptide to be available (secreted) and induced without requiring cell damage or death. This could be particularly important for the integrity and function of the cornea where inflammation, tissue damage, and scarring can 
result in significant loss of visual acuity. This unique situation contrasts with the epidermis in which keratinocytes are capable of producing icIL-1ra but not sIL-1ra (27).

Hammerberg et al. (51) demonstrated that icIL-1ra proteins are detected in the cytosol of normal epidermis and that this was significantly increased in psoriatic epidermis. Although in this report PCR studies detected transcripts of both icIL-1ra and sIL-1ra mRNA in the epidermis, it was indicated that this was likely due to the inclusion of cells such as Langerhans cells in the epidermal biopsies. No detectable sIL-1ra peptide was found in either normal or psoriatic epidermis by these investigators. Thus our study indicates that the human cornea uniquely produces IL-1ra. Further evaluation of the biologic behavior of corneal IL-1ra could lead to novel strategies to modulate inflammatory reactions in the cornea.

\section{Acknowledgments}

The authors thank Nancy Murray for her technical assistance.

This work was supported by National Institutes of Health grant RO1EY09218 and National Eye Institute Training grant T32 EY07123. Dr. Rosenbaum is a Senior Scholar supported by Research to Prevent Blindness, New York City.

\section{References}

1. Rosenbaum, J. T., J. R. Samples, S. H. Hefeneider, and E. L. Howes. 1987. Ocular inflammatory effects of intravitreal interleukin 1. Arch. Ophthalmol. 105:1117-1120

2. Ferrick, M. R., S. R. Thurau, M. H. Oppenheim, C. P. Herbort, M. Ni, C. O. C. Zachariae, K. Matsushima, and C.-C. Chan. 1991. Ocular inflammation stimulated by intravitreal interleukin-8 and interleukin-1. Invest. Ophthalmol. Vis. Sci. 32:1534-1539.

3. Fleisher, L. N., J. B. Ferrell, and M. C. McGahan. 1992. Synergistic uveitic effects of tumor necrosis factor-1 $\alpha$ and interleukin-1 $\beta$. Invest. Ophthalmol. Vis. Sci. 33:2120-2127.

4. Hoekzema, R., P. I. Murray, M. A. C. Van Haren, M. Helle, and A. Kijilstra. 1991. Analysis of interleukin-6 in endotoxin-induced uveitis. Invest. Ophthalmol. Vis. Sci. 32:88-95.

5. Rosenbaum, J. R., E. L. Howes Jr., R. M. Rubin, and J. R. Samples. 1988. Ocular inflammatory effect of intravitreally-injected tumor necrosis factor. Am. J. Pathol. 133:47-53.

6. Fleisher, L. N., J. B. Ferrell, and M. C. McGahan. 1990. Ocular inflammatory effects of intravitreally injected tumor necrosis factor-alpha and endotoxin. Inflammation. 14:325-335.

7. Wilson, S. E., Y. G. He, and S. A. Lloyd. 1992. EGF, EGF receptor, basic FGF, TGF beta-1, and IL-1 alpha mRNA in human corneal epithelial cells and stromal fibroblasts. Invest. Ophthalmol. Vis. Sci. 33:1756-1765.

8. Wilson, S. E., and S. A. Lloyd. 1991. Epidermal growth factor and its receptor, basic fibroblast growth factor, transforming growth factor beta-1, and interleukin-1 alpha messenger RNA production in human corneal endothelial cells. Invest. Ophthalmol. Vis. Sci. 32:2747-2756.

9. Shams, N. B., M. M. Sigel, and R. M. Davis. 1989. Interferon-gamma, staphylococcus aureus, and lipopolysaccharide/silica enhance interleukin-1 beta production by human corneal cells. Reg. Immunol. 2:136-148.

10. Cubitt, C. L., Z. Tang, C. A. Monteiro, R. N. Lausch, and J. E. Oakes. 1993. IL-8 gene expression in cultures of human corneal epithelial cells and keratocytes. Invest. Ophthalmol. Vis. Sci. 34:3199-3206.

11. Oakes, J. E., C. A. Monteiro, C. L. Cubitt, and R. N. Lausch. 1993. Induction of interleukin-8 gene expression is associated with herpes simplex virus infection of human corneal keratocytes but not human corneal epithelial cells. $J$. Virol. 67:4777-4784.

12. Planck, S. R., X. Huang, J. E. Robertson, and J. T. Rosenbaum. 1994. Cytoine mRNA levels in rat ocular tissues after systemic endotoxin treatment. Invest. Ophthalmol. Vis. Sci. 35:924-930.

13. Ansel, J. C., D. Tara, and J. T. Rosenbaum. 1991. Synthesis of interleukins 1 and 6 by human cornea. Invest. Ophthalmol. Vis. Sci. 32:676a. (Abstr.)

14. Grabner, G., T. A. Luger, B. M. Luger, G. Smolin, and J. O. Oh. 1983. Biologic properties of the thymocyte-activating factor (CETAF) produced by a rabbit corneal cell line (SIRC). Invest. Ophthalmol. Vis. Sci. 24:589-595.

15. Dinarello, C. A. 1991. Interleukin-1 and interleukin-1 antagonism. Blood. 77:1627-1652.

16. Dinarello, C. A. 1989. Interleukin-1 and its biologically related cytokines. Adv. Immunol. 44:153-205.
17. BenEzra, D., I. Hemo, and G. Mafzir. 1990. In vivo angiogenic activity of interleukins. Arch. Ophthalmol. 108:573-576.

18. Wawrousek, E. F., C. C. Chan, J. C. Lai, and I. Gery. 1994. Progressive inflammatory disease and neovascularization in the eyes of interleukin- $1 \beta$ transgenic mice. Invest. Ophthalmol. Vis. Sci. 35:1988a. (Abstr.)

19. Lai, J. C., E. F. Wawrousek, J. D. Sipe, S. M. Whitcup, C. C. Chan, and I. Gery. 1994. Ocular and systemic immunological profile of interleukin-1 $\beta$ (IL$1 \beta)$ transgenic mice. Invest. Ophthalmol. Vis. Sci. 35:1988a. (Abstr.)

20. Elner, V. M., R. M. Streiter, M. A. Pavilack, S. G. Elner, D. G. Remick, J. M. Danforth, and S. L. Kunkel. 1991. Human corneal interleukin-8. IL-1 and TNF-induced gene expression and secretion. Am. J. Pathol. 139:977-988.

21. Pavilack, M. A., V. M. Elner, S. G. Elner, R. F. Tood, and A. R. Huberg. 1992. Differential expression of human corneal and perilimbal ICAM-1 by inflammatory cytokines. Invest. Ophthalmol. Vis. Sci. 33:564-573.

22. Hannum, C. H., C. J. Wilcox, W. P. Arend, F. G. Joslin, D. J. Dripps, P. L. Heimdal, L. G. Armes, A. Sommer, S. P. Eisenberg, and R. C. Thompson. 1990. Interleukin-1 receptor antagonist activity of a human interleukin-1 inhibitor. Nature (Lond.). 343:336-340.

23. Eisenberg, S. P., R. J. Evans, W. P. Arend, E. Verderber, M. J. Brewer, C. H. Hannum, and R. C. Thompson. 1990. Primary structure and functional expression from complementary DNA of a human interleukin-1 receptor antagonist. Nature (Lond.). 343:341-346.

24. Dripps, D. J., B. J. Brandhuber, R. C. Thompson, and S. P. Eisenberg. 1991. IL-1 receptor antagonist binds to the $80-\mathrm{kDa}$ IL-1 receptor but does not initiate IL-1 signal transduction. J. Biol. Chem. 266:10331-10336.

25. Arend, W. P., and B. P. Coll. 1991. Interaction of recombinant monocytederived interleukin-1 receptor antagonist with rheumatoid synovial cells. Cytokine. 3:407-413.

26. Arend, W. P. 1993. Interleukin-1 receptor antagonist. Adv. Immunol. 54:167-227.

27. Bigler, C. F., D. A. Norris, W. L. Weston, and W. P. Arend. 1992. Interleukin-1 receptor antagonist production by human keratinocytes. J. Invest. Dermatol. 98:38-44.

28. Malyak, M., M. F. Smith, A. A. Abel, and W. P. Arend. 1993. Human peripheral blood mononuclear cells (PBMC) produce three forms of IL-1ra. Arthritis Rheum. 36:S154a. (Abstr).

29. Mancilla, J., P. Garcia, and C. A. Dinarello. 1993. The interleukin-1 receptor antagonist can either reduce or enhance the lethality of Klebsiella pneumoniae sepsis in newborn rats. Infect. Immun. 61:926-932.

30. Porat, R., D. D. Poutsiaka, L. C. Miller, E. V. Grandwitz, and C. A. Dinarello. 1992. Interleukin-1 (IL-1) receptor blockade reduces endotoxin and borrelia burgdorferi-stimulated IL-8 synthesis in human mononuclear cells. $F A$ SEB (Fed. Am. Soc. Exp. Biol.) J. 6:2482-2486.

31. Arend, W. P., H. G. Welgus, R. C. Thompson, and S. P. Eisenberg. 1990. Biological properties of recombinant human monocyte-derived interleukin1 receptor antagonist. J. Clin. Invest. 85:1694-1697.

32. Ohlsson, K., P. Bjork, M. Bergenfeldt, R. Hageman, and R. C. Thompson. 1990. Interleukin-1 receptor antagonist reduces mortality from endotoxin shock. Nature (Lond.). 348:550-552.

33. Cominelli, F., C. C. Nast, B. D. Clark, R. Schindler, R. Lierena, and V. E. Eysselein. 1990. Interleukin 1 (IL-1) gene expression, synthesis, and effect of specific IL-1 receptor blockade in rabbit immune complex colitis. J. Clin. Invest. 86:972-980.

34. Ramilo, O., X. Saez-Lloren, J. Mertsola, H. Jafari, K. D. Olsen, E. J. Hansen, M. Yoshinaga, S. Ohkawara, H. Nariuchi, and G. H. McCracken, Jr. 1990. Tumor necrosis factor alpha/cachectin and interleukin 1 beta initiate meningeal inflammation. J. Exp. Med. 172:497-507.

35. Rosenbaum, J. T., and R. S. Boney. 1992. Activity of an interleukin 1 receptor antagonist in rabbit models of uveitus. Arch. Ophthalmol. 110:547-549.

36. Badley, J. E., G. A. Bishop, T. St. John, and J. A. Frelinger. 1988. A simple, rapid method for the purification of poly A+ RNA. BioTechniques. 6:114116.

37. Armstrong, C. A., D. T. Tara, C. E. Hart, A. Kock, T. A. Luger, and J. C. Ansel. 1992. Heterogeneity of cytokine production by human malignant melanoma cells. Exp. Dermatol. 1:37-45.

38. Lef kovits, I., and B. Pernis. 1979. Immunological Methods. Academic Press, New York. 169-178.

39. Berger, A. E., D. B. Cartyer, S. O. Hankey, and R. N. McEwan. 1993. Cytokine regulation of the interleukin-1 receptor antagonist protein in U937 cells. Eur. J. Immunol. 23:39.

40. Girard, M. T., M. Matsubara, and M. E. Fini. 1991. Transforming growth factor- $\beta$ and interleukin- 1 modulate metalloproteinase expression by corneal stromal cells. Invest. Ophthalmol. Vis. Sci. 32:2441-2454.

41. Okamoto, J., H. Mishima, M., Nakamura, T., Nishida, and T. Otori. 1991. Interleukin 1 induction of collagenolytic activity by keratocytes cultured in three dimensional collagen gel. Invest. Ophthalmol. Vis. Sci. 32:1070a. (Abstr.)

42. Niederkorn, J. Y., J. S. Peeler, and J. Mellon. 1989. Phagocytosis of particulate antigens by corneal epithelial cells stimulates interleukin-1 secretion and migration of Langerhans cells into the central cornea. Reg. Immunol. 2:8390.

43. Tagawa, Y., F. Kitagawa, and H. Matsuda. 1991. IL-1 and IL-6 expressed 
on keratocytes in human herpetic stromal keratitis. Invest. Ophthalmol. Vis. Sci 32:953a. (Abstr.)

44. Staats, H. F., and R. N. Lausch. 1993. Cytokine expression in vivo during murine herpetic stromal keratitis. Effect of protective antibody therapy. J. Immunol. 151:277-283.

45. Arend, W. P. 1991. Interleukin 1 receptor antagonist. A new member of the interleukin 1 family. J. Clin. Invest. 88:1445-1451.

46. Haskill, S., G. Martin, L. Van Le, J. Morris, A. Peace, C. F. Bigler, G. J. Jaffe, C. Hammerberg, S. A. Sporn, S. Fong, W. P. Arend, and P. Ralph. 1991. cDNA cloning of an intracellular form of the human interleukin 1 receptor antagonist associated with epithelium. Proc. Natl. Acad. Sci. USA. 88:3681-3685.

47. Chan, L. S., C. Hammerberg, K. Kang, P. Sabb, A. Tavakkol, and K. D. Cooper. 1992. Human dermal fibroblast interleukin-1 receptor antagonist and interleukin- $1 \beta$ mRNA and protein are co-stimulated by phorbol ester. J. Invest. Dermatol. 99:315-322.
48. Krzesicki, R. F., C. A. Hatfield, M. J. Bienkowski, J. C. McGuire, G. E Winterrowd, D. L. Chapman, A. E. Berger, R. N. McEwan, D. B. Carter, J. G. Chosay, D. E. Tracey, and J. E. Chin. 1993. Regulation of expression of IL-1 receptor antagonist protein in human synovial and dermal fibroblasts. J. Immunol. 150:4008-4018.

49. Arend, W. P., F. G. Joslin, and F. J. Massoni. 1985. Effects of immune complexes on production by human monocyte of interleukin 1 or an interleukin 1 inhibitor. J. Immunol. 1344:3868-3875.

50. Arend, W. P., F. G. Joslin, R. C. Thompson, and C. H. Hannum. 1989 An IL-1 inhibitor from human monocytes: production and characterization of biologic properties. J. Immunol. 143:1851-1858.

51. Hammerberg, C., W. P. Arend, G. J. Fisher, L. S. Chan, A. E. Berger, J. S. Haskill, J. J. Voorhees, and K. D. Cooper. 1992. Interleukin-1 receptor antagonist in normal and psoriatic epidermis. J. Clin. Invest. 90:571-583. 